\title{
PENGARUH KECEMASAN MATEMATIS, PROBLEM STRESS MATEMATIKA DAN SELF-REGULATED LEARNING TERHADAP HASIL BELAJAR MATEMATIKA SISWA
}

\author{
Tanisa Diva Aryani ${ }^{1}$, Maylita Hasyim ${ }^{2}$ \\ ${ }^{1,2}$ Pendidikan Matematika, STKIP PGRI Tulungagung \\ E-mail: $\quad$ tdivaa95@gmail.com ${ }^{1)}$ \\ maylita@stkippgritulungagung.ac.id ${ }^{2)}$
}

Received 26 June 2018; Received in revised form 17 September 2018; Accepted 21 September 2018

\begin{abstract}
This study aims to analyze the influence of mathematical anxiety effects $\left(X_{1}\right)$, mathematical stress problems $\left(X_{2}\right)$ and self-regulated learning $\left(X_{3}\right)$ to the mathematics learning outcomes materials algebra operation $(Y)$ in the seventh grade students of SMP Negeri 1 Tugu Trenggalek. This research uses a quantitative approach with causal causative research. Data analysis techniques in this study using multiple regression analysis. Based on the results of data analysis, simultaneously on multiple linear regression, there is influence between mathematical anxiety $\left(X_{1}\right)$, mathematical stress problem $\left(X_{2}\right)$ and self-regulated learning $\left(X_{3}\right)$ to the mathematics learning outcomes equal to $44,6 \%$ with regression equation $Y=100,365+(-0,619) X_{1}+(-0.572) X_{2}+0.449 X_{3}$. Mathematical anxiety and mathematical stress problem negatively affects the mathematics learning outcomes, beside that self-regulated learning have a positive effect on mathematics learning outcomes.
\end{abstract}

Keywords: learning outcomes; mathematical anxiety; mathematical stress problem; self-regulated learning.

\section{PENDAHULUAN}

Fenomena saat ini banyak terjadi permasalahan di dunia pendidikan. Diantaranya banyak siswa yang mengalami kecemasan saat belajar matematika bahkan ada yang sampai mengalami stres karena belajar matematika. Hal tersebut jelas memberikan dampak yang besar terhadap hasil belajar matematika. Tidak dipungkiri banyak nilai matematika yang berada di bawah Kriteria Ketuntasan Minimal (KKM). Seperti penelitian yang dilakukan oleh Rahman (2015) menunjukkan bahwa kecemasan matematis berpengaruh negatif terhadap hasil belajar matematika, dimana semakin tinggi tingkat kecemasan, semakin rendah hasil belajar matematika, begitu pula sebaliknya. Dalam penelitian lain yang dilakukan oleh Wulandari dan Theis (2012) juga disebutkan bahwa problem stress matematika berpengaruh negatif yang signifikan terhadap hasil belajar matematika.

Dalam upaya peningkatan kualitas pendidikan khususnya matematika memerlukan usaha yang tidak hanya dilakukan oleh pihak eksternal, tapi juga harus ada upaya yang dilakukan oleh siswa itu sendiri salah satunya kesadaraan dan kemandirian dalam belajar. Jika kemandirian belajar (selfregulated learning) tidak ada dalam diri siswa tentu pihak guru, sekolah maupun orangtua sulit untuk melakukan peningkatan terhadap pendidikan matematika. Hal tersebut sesuai dengan hasil penelitian yang dilakukan oleh 
Etiafani dan Listiara (2015), bahwa semakin tinggi tingkat self-regulated learning maka semakin rendah kecemasan akademis siswa begitu pula sebaliknya. Dalam penelitian lain yang dilakukan oleh Masruroh dan Reza (2015), juga disebutkan bahwa kecemasan matematis berpengaruh negatif dan signifikan terhadap hasil belajar matematika.

Berdasarkan uraian di atas, penelitian ini bertujuan untuk menganalisis ada atau tidaknya pengaruh kecemasan matematis, problem stress matematika dan selfregulated learning secara simultan terhadap hasil belajar matematika materi Operasi Bentuk Aljabar pada pada siswa kelas VII SMP Negeri 1 Tugu tahun pelajaran 2017/2018.

\section{METODE PENELITIAN}

Subjek yang akan diteliti dalam penelitian ini adalah siswa kelas VII SMP Negeri 1 Tugu Trenggalek tahun pelajaran 2017/2018. Variabel X yang akan diteliti adalah kecemasan matematis, problem stres matematika dan self-regulated learning. Dari ketiga variabel tersebut akan dianalisis apakah ada pengaruh antara ketiga variabel $X$ tersebut terhadap variabel $\mathrm{Y}$ berupa hasil belajar matematika.

Berdasarkan dari permasalahan yang dikaji, penelitian ini menggunakan desain penelitian kuantitatif. Pendekatan yang digunakan adalah pendekatan kuantitatif. Jenis penelitian ini adalah penelitian assosiatif kausal. Penelitian ini menggunakan rancangan penelitian non-eksperimen.

Teknik pengumpulan data yang digunakan adalah teknik survey dan tes. Instrumen penelitian yang digunakan adalah: 1) angket kecemasan matematis; 2) angket problem stress matematika; 3) angket self-regulated learning; dan 4) soal tes hasil belajar matematika. Uji coba instrumen yang dilakukan adalah uji validitas dan uji reliabilitas. Keempat instrumen telah divalidasi oleh ketiga ahli dan dinyatakan layak untuk dijadikan instrumen pengumpul data penelitian ini. Dalam penelitian ini uji reliabillitas menggunakan rumus Alpha Cronbach untuk mengetahui indeks reliabilitas instrumen $\left(r_{11}\right)$. Hasil yang diperoleh dari perhitungan uji reliabilitas menggunakan Alpha Cronbach antara lain: 1) indeks reliabilitas $\left(r_{11}\right)$ angket kecemasan matematis sebesar 0,783 ; 2) indeks reliabilitas $\left(r_{11}\right)$ angket problem stres matematika sebesar 0,$826 ; 3$ ) indeks reliabilitas $\left(r_{11}\right)$ angket self-regulated learning sebesar 0,788 4) indeks reliabilitas $\left(r_{11}\right)$ tes hasil belajar matematika sebesar 0,713. Nilai indeks reliabilitas dari keempat instrumen tersebut lebih dari 0,700 , sehingga masing-masing instrumen dinyatakan reliabel.

Dalam penelitian ini terdiri oleh satu variabel terikat yaitu hasil belajar matematika materi operasi bentuk aljabar (Y). Sedangkan variabel bebas terdiri dari tiga variabel yaitu kecemasan matematis $\left(\mathrm{X}_{1}\right)$, problem stress matematika $\left(\mathrm{X}_{2}\right)$ dan selfregulated learning $\left(\mathrm{X}_{3}\right)$. Semua variabel dalam penelitian ini memiliki skala pengukuran interval.

Populasi dalam penelitian ini adalah seluruh siswa kelas VII SMP Negeri 1 Tugu pada tahun pelajaran 2017/2018 yang terdiri dari tujuh kelas dengan jumlah 220 siswa. Untuk menentukan jumlah sampel pada penelitian ini menggunakan Rumus Slovin. Berdasarkan rumus Slovin tersebut, diperoleh minimum sampel sebesar 69 siswa. Dalam penelitian ini, sampel yang digunakan adalah kelas VII C, VII D, dan VII F SMP Negeri 1 Tugu tahun pelajaran 2017/2018 
sejumlah 92 siswa yang dipilih dengan teknik cluster random sampling.

Data yang diperoleh akan dianalisis dengan menggunakan uji prasyarat dan uji hipotesis. Uji prasyarat dilakukan karena metode statistika yang digunakan adalah statistika parametrik. Adapun uji prasyarat yang dilakukan antara lain: uji kesetimbangan, uji normalitas dan uji linieritas. Sedangkan uji hipotesis yang digunakan adalah analisis regresi linier berganda. Asumsi klasik regresi linear berganda yang harus dipenuhi adalah uji identik, independen, residual berdistribusi normal dan multikolinearitas.

Hipotesis dalam penelitian ini adalah:

$\mathrm{H}_{0}$ : Tidak ada pengaruh variabel kecemasan matematis $\left(\mathrm{X}_{1}\right)$, problem stress matematika $\left(\mathrm{X}_{2}\right)$ dan self-regulated learning $\left(\mathrm{X}_{3}\right)$ secara simultan terhadap hasil belajar matematika materi operasi bentuk aljabar (Y)

$\mathrm{H}_{1}$ : Ada pengaruh variabel kecemasan matematis $\left(\mathrm{X}_{1}\right)$, problem stress matematika $\left(\mathrm{X}_{2}\right)$ dan self-re gulated learning $\left(\mathrm{X}_{3}\right)$ secara simultan terhadap hasil belajar matematika materi operasi bentuk aljabar (Y)

$\mathrm{H}_{0}$ ditolak jika $\mathrm{t}$ hitung jatuh di dalam daerah kritik

\section{HASIL PENELITIAN DAN PEMBAHASAN}

Berdasarkan hasil uji kesetimbangan menggunakan metode analisis variansi satu jalur (one-way ANOVA) dengan bantuan program IBM SPSS versi 21 maka diperoleh kesimpulan rata-rata kemampuan ketiga kelas (VII C, VII D, dan VII F) mempunyai kemampuan yang sama (setimbang), sehingga ketiga kelas tersebut dapat dijadikan satu kesatuan sampel.

Berdasarkan perhitungan menggunakan Kolmogorov-Smirnov dengan bantuan program IBM SPSS versi 21, data dikatakan berdistribusi normal apabila nilai $K S_{\text {hitung }}<K S_{\text {tabel }}$. Untuk data hasil tes hasil belajar matematika diperoleh $K S_{\text {hitung }}$ sebesar 0,065 , skor angket kecemasan matematis diperoleh $K S_{\text {hitung }}$ sebesar 0,094, skor angket problem stress matematika diperoleh $K S_{\text {hitung }}$ sebesar 0,047 , skor angket self-regulated learning diperoleh $K S_{\text {hitung }}$ sebesar 0,094 dimana nilainilai tersebut kurang kurang dari $K S_{\text {tabel }}$ sebesar 0,1395. Berdasarkan hasil tersebut, maka data hasil tes hasil belajar matematika, angket kecemasan matematis, angket problem stress matematika dan angket self-regulated learning dapat dinyatakan data berdistribusi normal sehingga uji normalitas terpenuhi.

Berdasarkan perhitungan uji linieritas menggunakan program IBM SPSS versi 21, data dinyatakan ada hubungan linier antara $\mathrm{X}$ dan $\mathrm{Y}$ apabila nilai $F_{\text {hitung }}<F_{\text {tabel }}$. Untuk data hasil angket kecemasan matematis terhadap tes hasil belajar matematika diperoleh $F_{\text {hitung }}$ sebesar 1,043, angket problem stress matematika terhadap tes hasil belajar matematika diperoleh $F_{\text {hitung }}$ sebesar 1,043 dan data hasil angket selfregulated learning terhadap tes hasil belajar matematika diperoleh $F_{\text {hitung }}$ sebesar 0,900 dimana nilai-nilai tersebut kurang kurang dari $F_{\text {tabel }}$ sebesar 1,70. Dari hasil tersebut, maka ada hubungan linier antara antara $\mathrm{X}$ dan $\mathrm{Y}$ sehingga uji prasyarat terpenuhi. Setelah uji prasyarat terpenuhi, selanjutnya dilakukan uji hipotesis. 
Semua uji prasyarat telah terpenuhi, selanjutnya dilakukan analisis statistik deskriptif sebagai gambaran awal data ketiga variabel penelitian yaitu data hasil angket kecemasan matematis, hasil angket problem stress matematika, hasil angket self-regulated learning dan tes hasil belajar matematika materi operasi bentuk aljabar.

Tabel 1. Statistik Deskriptif Perhitungan Angket Kecemasan Matematis, Problem Stress Matematika, Self-Regulated Learning dan Tes Hasil Belajar Matematika

\begin{tabular}{|c|c|c|c|c|}
\hline $\begin{array}{c}\text { Statistik } \\
\text { Deskriptif }\end{array}$ & $\begin{array}{c}\text { Kecemasan } \\
\text { Matematis }\left(\boldsymbol{X}_{\mathbf{1}}\right)\end{array}$ & $\begin{array}{c}\text { Problem Stres } \\
\text { Matematika }\left(\boldsymbol{X}_{\mathbf{2}}\right)\end{array}$ & $\begin{array}{c}\text { Self-Regulated } \\
\text { Learning }\left(\boldsymbol{X}_{\mathbf{3}}\right)\end{array}$ & $\begin{array}{c}\text { Hasil Belajar } \\
\text { Matematika } \boldsymbol{Y})\end{array}$ \\
\hline Rata-rata & 77,03 & 82,21 & 103,86 & 14,11 \\
\hline Skor Tertinggi & 99 & 101 & 146 & 26 \\
\hline Skor Terendah & 36 & 55 & 67 & 2 \\
\hline Variansi & 116,076 & 105,221 & 170,826 & 40,911 \\
\hline $\begin{array}{c}\text { Standar } \\
\text { Deviasi }\end{array}$ & 10,774 & 10,258 & 13,070 & 6,396 \\
\hline Range & 63 & 46 & 79 & 24 \\
\hline
\end{tabular}

Berdasarkan data pada Tabel 1 diperoleh informasi perhitungan dari masing-masing variabel penelitian sebagai berikut.

1. Pada kecemasan matematis diperoleh rata-rata (mean) skor angket adalah 77,03 dari skor maksimal 150. Standar deviasi kecemasan matematis sebesar 10,774 dan variansi 116,076 . Skor tertinggi 99, skor terendah 36 , daan range 63.

2. Pada problem stress matematika diperoleh rata-rata (mean) skor angket adalah 82,21 dari skor maksimal 150. Standar deviasi problem stres matematika sebesar 10,258 dan variansi 105,221. Skor tertinggi 101, skor terendah 55, daan range 46.
3. Pada self-regulated learning diperoleh rata-rata (mean) skor angket adalah 103,86 dari skor maksimal 150. Standar deviasi kecemasan matematis sebesar 13,070 dan variansi 170,826 . Skor tertinggi 146, skor terendah 67, daan range 79 .

4. Pada hasil belajar matematika diperoleh rata-rata/mean skor angket adalah 14,11 dari skor maksimal 150. Standar deviasi hasil belajar matematika sebesar 6,396 dan variansi 40,911. Skor tertinggi 26, skor terendah 2, daan range 24 .

Selanjutnya dilakukan uji hipotesis menggunakan metode regresi linear berganda dengan bantuan program IBM SPSS versi 21. Berikut output IBM SPSS:

Tabel 2. Output Uji Signifikansi Parameter - Parsial

Coefficients $^{\mathbf{a}}$

\begin{tabular}{|ll|r|r|r|r|r|}
\hline \multirow{2}{*}{ Model } & \multicolumn{2}{|c|}{$\begin{array}{c}\text { Unstandardized } \\
\text { Coefficients }\end{array}$} & $\begin{array}{c}\text { Standardized } \\
\text { Coefficients }\end{array}$ & \multirow{2}{*}{ S } & \multirow{2}{*}{ Sig. } \\
\cline { 2 - 5 } & \multicolumn{1}{|c|}{ B } & Std. Error & \multicolumn{1}{c|}{ Beta } & & \\
\hline \multirow{2}{*}{1} & (Constant) & 100,365 & 38,970 & & 2,575 &, 012 \\
\cline { 3 - 5 } & Kecemasan Matematis &,- 619 &, 228 &,- 281 & $-2,712$ &, 008 \\
\hline
\end{tabular}


ISSN 2089-8703 (Print) Vol. 7, No. 2 (2018) 243-252

ISSN 2442-5419 (Online)

\begin{tabular}{|l|r|r|r|r|r|}
\hline $\begin{array}{l}\text { Problem Stress } \\
\text { Matematika }\end{array}$ &,- 572 &, 273 &,- 248 & $-2,094$ &, 039 \\
Self Regulated Learning &, 449 &, 198 &, 248 & 2,267 &, 026 \\
\hline
\end{tabular}

a. Dependent Variable: Hasil Belajar

Tabel 2 menunjukkan hasil berikut:

1. Konstanta $\left(\beta_{0}\right)=100,365$;

2. Koefisien Kecemasan Matematis $\left(\beta_{1}\right)=-0,619$;

3. Koefisien Problem Stress Matematika $\left(\beta_{2}\right)=-0,572$;

4. Koefisien Self-Regulated Learning $\left(\beta_{3}\right)=0,449$.

Sehingga persamaan garis regresinya adalah:

$\hat{Y}=100,365+(-0,619) X_{1}+(-0,572) X_{2}+0,449 X_{3}$

Artinya setiap kenaikan 1 satuan skor kecemasan matematis dengan asumsi variabel lain $\left(\mathrm{X}_{2}\right.$ dan $\left.\mathrm{X}_{3}\right)$ konstan akan menurunkan hasil belajar matematika sebesar 0,619 dengan konstanta 100,365. Selain itu, setiap kenaikan 1 satuan skor problem stress matematika dengan asumsi variabel lain $\left(\mathrm{X}_{1}\right.$ dan $\left.\mathrm{X}_{3}\right)$ konstan akan menurunkan hasil belajar matematika sebesar 0,572 dengan konstanta 100,365 dan setiap kenaikan 1 satuan skor self-regulated learning dengan asumsi variabel lain $\left(\mathrm{X}_{1}\right.$ dan $\left.\mathrm{X}_{2}\right)$ konstan akan meningkatkan hasil belajar matematika sebesar 0,449 dengan konstanta 100,365.

Tabel 2 juga menunjukkan hasil uji signifikansi parameter secara parsial dari $t_{\text {hitung } 1}$ sebesar $-2,712 \in D K$ sehingga $\mathrm{H}_{0}$ ditolak; $t_{\text {hitung } 2}$ sebesar $-2,094 \in D K$ sehingga $\quad \mathrm{H}_{0}$ ditolak; $t_{\text {hitung } 3}$ sebesar $2,267 \in D K$ dengan $D K=$

$\left\{t \mid t<-t_{0,05 ; 90}\right.$ atau $\left.t>t_{0,05 ; 90}\right\}=$ $\{t \mid t<-1,9867$ atau $t>1,9867\}$ sehingga $\mathrm{H}_{0}$ ditolak. Jika $\mathrm{H}_{0}$ ditolak, maka koefisien $\beta_{i}$ berarti sehingga secara parsial ada pengaruh antara kecemasan matematis, problem stress matematika dan self-regulated learning terhadap hasil belajar matematika.

Berikut hasil uji signifikansi parameter secara serentak:

Tabel 3. Output Uji Signifikansi Parameter - Serentak

ANOVA ${ }^{\mathrm{a}}$

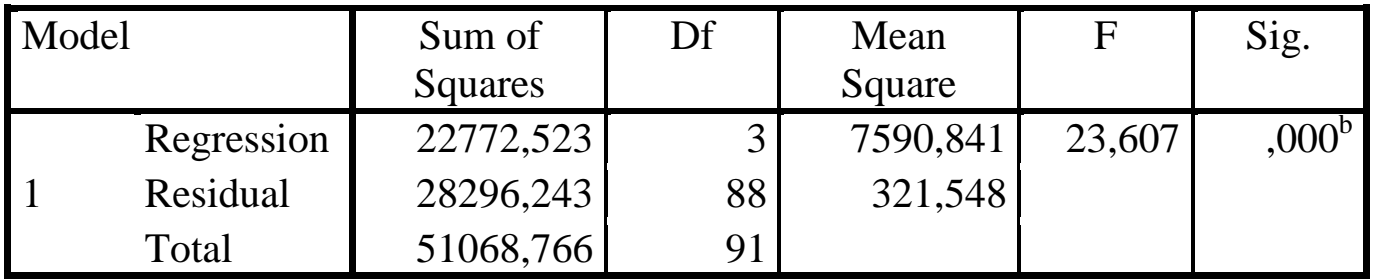

a. Dependent Variable: Hasil Belajar

b. Predictors: (Constant), Self Regulated Learning, Kecemasan Matematis, Problem Stress Matematika

Tabel 3 menunjukkan hasil uji signifikansi koefisien regresi ganda secara serentak yaitu $F_{\text {hitung }}$ sebesar 23,607 termasuk dalam daerah kritik, dimana $D K=\{F \mid F>2,72\}$ sehingga $\mathrm{H}_{0}$ ditolak. Jika $\mathrm{H}_{0}$ ditolak, maka hubungan linier ganda antara $\mathrm{X}_{1}, \mathrm{X}_{2}$ dan $\mathrm{X}_{3}$ dengan $\mathrm{Y}$ berarti sehingga terdapat pengaruh kecemasan matematis, problem stress matematika dan self-regulated learning secara simultan terhadap hasil belajar matematika. 
Berdasarkan uji signifikansi parameter baik secara parsial atau serentak, menimpulkan bahwa ketiga variabel bebas berpengaruh terhadap variabel terikat. Selanjutnya melakukan uji asumsi klasik, yaitu uji identik, independent, distribusi normal dan multikolinearitas.

Tabel 4. Output Uji Asumsi Identik

Coefficients $^{\mathbf{a}}$

\begin{tabular}{|c|c|c|c|c|c|c|}
\hline \multirow{2}{*}{\multicolumn{2}{|c|}{ Model }} & \multicolumn{2}{|c|}{$\begin{array}{l}\text { Unstandardized } \\
\text { Coefficients }\end{array}$} & \multirow{2}{*}{$\begin{array}{c}\text { Standardized } \\
\text { Coefficients } \\
\text { Beta }\end{array}$} & \multirow[t]{2}{*}{$\mathrm{T}$} & \multirow[t]{2}{*}{ Sig. } \\
\hline & & B & Std. Error & & & \\
\hline \multirow{4}{*}{1} & (Constant) & $1,359 \mathrm{E}-013$ & 38,970 & &, 000 & $\overline{1,000}$ \\
\hline & $\begin{array}{l}\text { Kecemasan } \\
\text { Matematis }\end{array}$ &, 000 & ,228 & ,000 & ,000 & 1,000 \\
\hline & $\begin{array}{l}\text { Problem Stress } \\
\text { Matematika }\end{array}$ &, 000 & ,273 &, 000 &, 000 & 1,000 \\
\hline & $\begin{array}{l}\text { Self Regulated } \\
\text { Learning }\end{array}$ &, 000 & ,198 & ,000 & ,000 & 1,000 \\
\hline
\end{tabular}

Tabel 4 menunjukkan $P_{\text {value }}=$ 1,$000 ; 1,000 ; 1,000$ dimana $P_{\text {value }}>$ 0,05 yang berarti kecemasan matematis $\left(\mathrm{X}_{1}\right)$, problem stress matematika $\left(\mathrm{X}_{2}\right)$ dan self-regulated learning $\left(\mathrm{X}_{3}\right)$ tidak berpengaruh terhadap Absolute Residual sehingga variansi residual identik atau uji asumsi identik telah terpenuhi.

Tabel 5. Output Uji Asumsi Independen

Model Summary ${ }^{\text {b }}$

\begin{tabular}{|l|r|r|r|r|r|}
\hline $\begin{array}{l}\text { Mode } \\
1\end{array}$ & R & R Square & $\begin{array}{c}\text { Adjusted R } \\
\text { Square }\end{array}$ & $\begin{array}{l}\text { Std. Error of } \\
\text { the Estimate }\end{array}$ & Durbin-Watson \\
\hline 1 &, $668^{\mathrm{a}}$ &, 446 &, 427 & 17,932 & 1,713 \\
\hline
\end{tabular}

a. Predictors: (Constant), Self Regulated Learning, Kecemasan Matematis, Problem Stress Matematika

b. Dependent Variable: Hasil Belajar

Tabel 5 menunjukkan nilai Durbin Watson $(D W)=1,713$ sehingga uji asumsi independen terpenuhi atau terjadi independen. Tabel 5 juga menunjukkan nilai $\mathrm{R}^{2}=0,446$. Dapat diartikan bahwa $44,6 \%$ nilai-nilai $\mathrm{Y}$ dapat dijelaskan oleh model regresi linier berdasarkan nilai $\mathrm{X}_{1}, \mathrm{X}_{2}, \mathrm{X}_{3}$ dari definisi tersebut. Dapat disimpulkan bahwa koefisien determinan menyatakan bagian dari variansi total yang dijelaskan oleh model hubungan linier berganda yang diperoleh. 
ISSN 2089-8703 (Print) Vol. 7, No. 2 (2018) 243-252

ISSN 2442-5419 (Online)

Tabel 6. Output Uji Asumsi Normalitas Residual

One-Sample Kolmogorov-Smirnov Test

\begin{tabular}{|c|c|c|}
\hline & & RESIDUAL_4 \\
\hline $\mathrm{N}$ & & 92 \\
\hline Normal Parametera, ${ }^{a, b}$ & Mean & ,0000 \\
\hline & Std. Deviation & 17,63371 \\
\hline & Absolute & ,066 \\
\hline Most Extreme Differences & Positive & ,066 \\
\hline & Negative &,- 043 \\
\hline Kolmogorov-Smirnov Z & & ,629 \\
\hline Asymp. Sig. (2-tailed) & & ,824 \\
\hline
\end{tabular}

a. Test distribution is Normal.

b. Calculated from data.

Tabel 6 menunjukkan uji normalitas residual yaitu didapat $K S_{\text {hitung }}$ sebesar $0,066 \notin D K$ dengan
$D K=\{K S \mid K S>0,1395\}$ sehingga $\mathrm{H}_{0}$ diterima. Jika $\mathrm{H}_{0}$ diterima, maka residual berdistribusi normal.

Tabel 7. Output Uji Asumsi Multikolinieritas

Coefficients $^{\mathrm{a}}$

\begin{tabular}{|c|c|c|c|c|c|c|c|c|}
\hline \multirow{2}{*}{\multicolumn{2}{|c|}{ Model }} & \multicolumn{2}{|c|}{$\begin{array}{c}\text { Unstandardized } \\
\text { Coefficients }\end{array}$} & \multirow{2}{*}{$\begin{array}{c}\begin{array}{c}\text { Standardized } \\
\text { Coefficients }\end{array} \\
\text { Beta }\end{array}$} & \multirow[t]{2}{*}{$\mathrm{T}$} & \multirow[t]{2}{*}{ Sig. } & \multicolumn{2}{|c|}{$\begin{array}{c}\text { Collinearity } \\
\text { Statistics }\end{array}$} \\
\hline & & B & $\begin{array}{l}\text { Std. } \\
\text { Error }\end{array}$ & & & & Tolerance & VIF \\
\hline \multirow{4}{*}{1} & (Constant) & 100,365 & 38,970 & & 2,575 &, 012 & & \\
\hline & $\begin{array}{l}\text { Kecemasan } \\
\text { Matematis }\end{array}$ &,- 619 & ,228 &,- 281 & $-2,712$ & ,008 &, 585 & 1,709 \\
\hline & $\begin{array}{l}\text { Problem Stres } \\
\text { Matematika }\end{array}$ &,- 572 &, 273 &,- 248 & $-2,094$ & ,039 & ,449 & 2,225 \\
\hline & $\begin{array}{l}\text { Self } \\
\text { Regulated } \\
\text { Learning }\end{array}$ & ,449 & ,198 & ,248 & 2,267 & ,026 &, 528 & 1,895 \\
\hline \multicolumn{4}{|c|}{$\begin{array}{l}\text { Tabel } 7 \text { menunjukkan nilai } \mathrm{VIF}_{1} \\
\text { sebesar } 1,709 ; \mathrm{VIF}_{2} \text { sebesar } 2,225 ; \mathrm{VIF}_{3} \\
\text { sebesar } 1,895 \text {; dimana nilai-nilai } \mathrm{VIF} \\
\text { tersebut kurang dari } 10 \text { (VIF }<10 \text { ) } \\
\text { sehingga dapat dikatakan tidak terjadi } \\
\text { multikolinieritas antar variabel } \\
\text { independen. } \\
\text { Dalam meningkatkan hasil belaiar }\end{array}$} & \multicolumn{5}{|c|}{$\begin{array}{l}\text { guru dan sekolah, namun juga sangat } \\
\text { dipengaruhi oleh faktor internal siswa } \\
\text { itu sendiri. Diantara faktor internal yang } \\
\text { mempengaruhi hasil belajar adalah self- } \\
\text { regulated learning, kecemasan } \\
\text { matematis dan problem stress } \\
\text { matematika. Ketiga variabel tersebut } \\
\text { sangat mempengaruhi tinggi rendahnya } \\
\text { hasil belajar matematika. }\end{array}$} \\
\hline
\end{tabular}

matematika terutama pada materi operasi bentuk aljabar, tidak hanya dipengaruhi dari faktor eksternal seperti 
Begitu pula dengan problem stress matematika, suatu hal yang seringkali menghambat keberhasilan siswa dalam meningkatkan hasil belajar matematika. Penelitian yang dilakukan Wulandari dan Theis (2012) menyimpulkan bahwa problem stres matematika berpengaruh negatif dan signifikan terhadap hasil belajar matematika. Sejalan dengan penelitian yang dilakukan Gaol (2016) menyatakan bahwa jika kemampuan untuk menangani stres tidak cukup dan tuntutan berlebihan, stres akan terus meningkat. Akibatnya, stres berkontribusi negatif pada kesehatan fisik dan psikologis. Jika terjadi demikian, sejumlah peneliti menemukan bahwa siswa yang mengalami stres akan cenderung menunjukkan kemampuan akademik yang menurun (Gaol, 2016). Dalam jurnal penelitian yang ditulis oleh Wibowo, dkk (2007) juga menyatakan bahwa siswa yang mengalami stres mengakibatkan prestasi belajar peserta didik menurun karena tidak optimal dalam belajar. Hal tersebut sesuai dengan penjelasan Aryani (2016, hal. 53) dalam bukunya yang berjudul Stres Belajar menyatakan bahwa stres akan mengacaukan kinerja pikiran siswa dalam melakukan segala aktifitasnya termasuk belajar. Desmita (2010, hal. 291) dalam bukunya yang berjudul Psikologi Perkembangan Peserta Didik menyatakan kondisi stres yang dialami siswa akan mempengaruhi prestasi belajar siswa. Untuk mengatasi hal tersebut diperlukan kemampuan siswa dalam mengelola stres agar stres tidak berpengaruh negatif terhadap didi siswa itu sendiri sesuai dengan penelitian Guyana, dkk. (2015) bahwa terdapat pengaruh yang signifikan dan positif manajemen stres terhadap hasil belajar. Selain itu, sebagai upaya menangani kondisi problem stress siswa, hendaknya sekolah mampu menciptakan iklim sekolah yang kondusif, melaksanakan program pelatihan penanggulangan stres dan mengembangkan reliensi peserta didik (Desmita, 2010, hal. 301-304).

Sebagai seorang siswa selfregulated learning harusnya dimiliki, agar setiap diri siswa bisa mengelola kebutuhan belajarnya sendiri tanpa bergantung pada orang lain. Jika kesadaran dalam belajar ada dalam siswa, tentu akan meningkatkan kualitas hasil belajar. Dengan demikian ketiga hal tersebut adalah beberapa faktor dari dalam siswa yang sangat mempengaruhi hasil belajar. Ruliyanti (2014) menyatakan bahwa terdapat hubungan yang signifikan antara self-regulated learning dengan prestasi akademik matematika. Zahary (2015) dalam penelitiannya menyimpulkan bahwa self-regulated learning merupakan faktor internal yang berperan dalam pencapaian hasil atau prestasi belajar siswa yang optimal namun tetap dibutuhkan pengarahan yang baik dari guru agar tercapai prestasi akademik yang lebih optimal. Sejalan dengan hasil penelitian penelitian Rahmiyati (2017) yang menunjukkan bahwa ada pengaruh positif dari self-regulated learning terhadap prestasi belajar siswa. Begitu pula penelitian Astutik dan Wasiti (2016) juga menunjukkan terdapat pengaruh yang signifikan antara selfregulated learning terhadap hasil belajar siswa. Sejalan dengan penelitian Sucipto (2014) menunjukkan bahwa ada pengaruh signifikan antara selfregulated learning (SRL) terhadap prestasi siswa. Berdasarkan dari beberapa penelitian tersebut menguatkan bahwa self-regulated learning mempengaruhi hasil belajar matematika, sehingga semakin tinggi self-regulated learning-nya semakin tinggi pula hasil belajar matematikanya, begitu pula sebaliknya. 


\section{KESIMPULAN DAN SARAN}

Berdasarkan hasil penelitian dan pembahasan, disimpulkan bahwa kecemasan matematis, problem stress matematika dan self-regulated learning secara simultan memiliki pengaruh yang signifikan terhadap hasil belajar matematika. Kecemasan matematis dan problem stress matematika berpengaruh negatif terhadap hasil belajar matematika. Berdasarkan hal tersebut siswa yang memiliki tingkat kecemasan matematis dan problem stress matematika yang tinggi akan mempengaruhi penurunan hasil belajar matematika begitu pula sebaliknya. Berbeda dengan self-regulated learning yang berpengaruh positif terhadap hasil belajar matematika. Jika siswa yang memiliki tingkat self-regulated learning yang tinggi maka akan berpengaruh terhadap peningkatan hasil belajar matematika begitu pula sebaliknya.

$$
\text { Berdasarkan kesimpulan }
$$

tersebut, maka dapat disarankan sebagai berikut.

1. Siswa hendaknya mampu mengelola dan meminimalisir kecemasan matematis dan problem stress matematika serta dapat mengembangkan self-regulated learning untuk meningkatkan hasil belajar matematika.

2. Guru diharapkan dapat memberikan arahan dan motivasi kepada siswa untuk mengelola dan meminimalisir kecemasan matematis dan problem stress matematika serta dapat mengembangkan self-regulated learning sehingga dapat membantu memudahkan siswa dalam meningkatkan hasil belajar matematika.

\section{DAFTAR PUSTAKA}

Aryani, F. (2016). Stres Belajar: Suatu

Pendekatan dan Intervensi

Konseling. Makassar: Edukasi

Mitra Grafika. Diambil dari

Http://Eprints.Unm.Ac.Id/2478/1/

Buku - Stres Belajar.Pdf

Astutik, S. M., \& Wasiti. (2016).

Pengaruh Self Regulated Learning dan Ketersediaan Fasilitas Belajar terhadap Hasil Belajar Siswa pada Mata Pelajaran Otomatisasi

Perkantoran. Jurnal Pendidikan

Bisnis \& Manajemen, 2(1).

Diambil dari

Http://Journal2.Um.Ac.Id/Index.Ph $\mathrm{p} / \mathrm{Jpbm} /$ Article/View/1690

Desmita. (2010). Psikologi

Perkembangan Peserta Didik (2

Ed.). Bandung: PT Remaja

Rosdakarya.

Ekawati, A. (2016). Pengaruh

Kecemasan terhadap Hasil Belajar

Matematika Siswa Kelas VII

SMPN 13 Banjarmasin. Jurnal

Pendidikan Matematika, 1(3), 164-169.

Etiafani, E., \& Listiara, A. (2015). Self-

Regulated Learning dan

Kecemasan Akademik pada Siswa

SMK. Jurnal Empati, 4(4), 144149.

Gaol, N. T. L. (2016). Teori Stres:

Stimulus, Respons, dan

Transaksional. Buletin Psikologi, 24(1), 1-11.

Https://Doi.Org/10.22146/Bpsi.112 24

Guyana, C., Witarsa, \& Achmadi.

(2015). Pengaruh Manajemen Stres

terhadap Hasil Belajar Siswa

dalam Pembelajaran Akuntansi

SMK Negeri 1 Pontianak, 1-13.

Londo, T., Wenas, R. J., \&

Sulistyaningsih, M. (2015).

Pengaruh Kecemasan Matematika terhadap Hasil Belajar. Jsme Mipa

Unima, 3(1). Diambil dari 
Http://Id.Portalgaruda.Org/?Ref=B rowse $\&$ Mod=Viewarticle $\&$ Article $=303691$

Masruroh, L., \& Reza, M. D. (2015). Pengaruh Kecemasan Siswa pada Matematika terhadap Hasil Belajar Matematikadi SMP. Jurnal Pendidikan Matematika Stkip Pgri Sidoarjo, 3(2), 175-186.

Rahman, U., Nursalam, \& Tahir, M. R. (2015). Pengaruh Kecemasan dan Kesulitan Belajar Matematika terhadap Hasil Belajar Matematika pada Siswa Kelas X MA Negeri 1 Watampone Kabupaten Bone. Mapan: Jurnal Matematika dan Pembelajaran, 3(1), 85-102. Diambil dari Http://Journal.UinAlauddin.Ac.Id/Index.Php/Mapan/ Article/View/2752

Rahmiyati, A. (2017). Pengaruh Self Regulated Learning terhadap Prestasi Belajar Siswa Kelas X pada Mata Pelajaran Ekonomi. Jurnal Pendidikan Dan Pembelajaran, 6(9). Diambil dari Http://Jurnal.Untan.Ac.Id/Index.Ph $\mathrm{p} / \mathrm{Jpdpb} /$ Article/View/21609

Ruliyanti, B. D. (2014). Hubungan Antara Self-Efficacy dan SelfRegulated Learning dengan Prestasi Akademik Matematika Siswa SMAN 2 Bangkalan. Character, 3(2), 1-7.

Sucipto. (2014). Pengaruh Self-

Regulated Learning dan Dukungan Orang Tua terhadap Hasil Belajar Peserta Didik pada Mata Pelajaran Ekonomi Program Studi IPS SMA Negeri di Kota Jombang. Jurnal Ekonomi Pendidikan Dan Kewirausahaan, 2(2), 237-251. Diambil dari Https://Journal.Unesa.Ac.Id/Index. Php/Jepk/Article/View/733/580 Syafri, F. S. (2017). Ada Apa Dengan Kecemasan Matematika? Journal Of Medives, 1(1), 59-65. Diambil dari Http://E-Journal.IkipVeteran.Ac.Id/Index.Php/Matemati ka

Wibowo, A., Kasih, F., \& Yandri, H. (2007). Faktor Penyebab Peserta Didik Stres dalam Belajar di Kelas VIII SMPN 4 Sutera Kabupaten Pesisir Selatan. Bimbingan dan Konseling, 1(1).

Wulandari, E., \& Theis, R. (2012). Pengaruh Problem Stres Matematika Sekolah Terhadap Hasil Belajar Matematika Siswa kelas XI IPA SMA Negeri 4 Kota Jambi T. A 2009/2010. Edumatica, 2(1), 26-35.

Zahary, M. (2015). Meningkatkan Prestasi Belajar Matematika Siswa Melalui Strategi Self Regulated Learning. Seminar Nasional Matematika dan Pendidikan Matematika Uny, 24(Pasal 3), 163168. 